\title{
СУCПIIИЬHO-ГEOГPAक/Ч/II GOCIIAKEHII
}

УДК 911.3

https://doi.org/10.15407/ugz2017.04.020

\author{
Г.П. Підерушний', К.П. Коваль' ${ }^{2}$ Й.Й. Молнар ${ }^{3}$, Е. Гомокі ${ }^{4}$ \\ ${ }^{1}$ Інститут географії Національної академії наук України, Київ \\ ${ }^{2}$ Інститут географрії Угорської академії наук, Будапешт \\ ЗЗакарпатський угорський інститут ім. Ференца Ракоці II, Берегове \\ ${ }^{4}$ Ніредьгазький університет, Ніредьгаза, Угорщина
}

\section{УКРАЇНСЬКО-УГОРСЬКЕ ПРИКОРДОННЯ: МОЖЛИВОСТІ ТА ПЕРСПЕКТИВИ РОЗВИТКУ В КОНТЕКСТІ ЄВРОПЕЙСЬКИХ ІНТЕГРАЦІЙНИХ ПРОЦЕСІВ*}

\begin{abstract}
Мета статті - розкрити особливості розвитку українсько-угорського прикордоння як важливої територіальної ланки у системі європейської інтеграції України. Дано аналіз нормативно-правового забезпечення українсько-угорського транскордонного співробітництва, розкрито його нинішні масштаби та спрямованість. Досліджено територіальну організацію українсько-угорського транскордонного регіону. На основі експертного анкетування досліджено питання, що стосуються проблем спільного використання наявних природних ресурсів прикордоння, рівня доходів та якості життя населення по обидва боки кордону, можливостей формування транскордонних економічних кластерів, проблем транскордонної міграції населення та екологічної безпеки тощо. Наголошено, що можливості Закарпаття з високою часткою угорців, які проживають у прикордонних районах області й мають тісні трудові, культурно-історичні, бізнесові та інші зв'язки з Угорщиною, є особливо сприятливими для євроінтеграційних процесів. Запропоновано систему заходів, спрямованих на активізацію соціально-економічного розвитку українсько-угорського транскордонного регіону.
\end{abstract}

Ключові слова: транскордонний регіон; транскордонне співробітнищтво; європейська інтеграџія; украӥнськоугорське прикордоння; Україна; Угорщина.

\section{G.P. Pidhrushnyi', K.P. Koval', Y.Y. Molnar ${ }^{3}$, E. Homocki ${ }^{4}$}

${ }^{1}$ Institute of Geography of the National Academy of Sciences of Ukraine, Kyiv

${ }^{2}$ Geographical Institute of Hungarian Academy of Sciences, Budapest

${ }^{3}$ Ferenc Rákóczi II Transcarpathian Hungarian Institute, Berehovo

${ }^{4}$ University of Nîreigas, Nîreigas, Hungary

UKRAINIAN-HUNGARIAN BORDERLAND: POSSIBILITIES AND PERSPECTIVES OF DEVELOPMENT IN THE CONTEXT OF EUROPEAN INTEGRATION PROCESSES

The aim of the article is to define peculiarities of development of Ukrainian-Hungarian borderland as an important link in the system of European integration of Ukraine. The legislative framework of Ukrainian-Hungarian cross-border cooperation is analyzed as well as its current scale and orientation. Territorial organization of Ukrainian-Hungarian cross-border region has been researched. Involving a method of expert questioning, a number of issues have been researched including aspects of mutual using of available natural resources of the borderland, distribution of income level and live quality on both sides of the border, possibilities of development of cross-border economical clusters, cross-border migration and ecological safety etc. It is emphasized that the potential of Transcarpathia with a high proportion of Hungarians living in the border areas of the region and having close labor, cultural and historical, business and other ties with Hungary are especially favorable for European integration processes. The system of actions is offered to activate socio-economic development of Ukrainian-Hungarian crossborder region.

Keywords: cross-border region; cross-border cooperation; European integration; Ukrainian-Hungarian borderland; Ukraine; Hungary.

*Статтю підготовлено за матеріалами міжнародного наукового проекту «Регіональні процеси і глобальні виклики в Україні та Угорщині після кризи 2008 року», який виконується Інститутом географії НАН України та Інститутом географії Угорської академії наук (термін виконання 2016 - 2018 рр.)

() Г.П. Підәрушний, К.П. Коваль, Й.Й. Молнар, Е. Гомокі, 2017

ISSN 1561-4980. Ukr. geogr. ž, 2017, 4(100) 


\section{Актуальність теми дослідження}

Актуалізація проблем розвитку прикордонних 3 Свропейським Союзом регіонів зумовлюється низкою чинників. Передусім, це безпекова проблема $\mathrm{EC}$, яка потребує створення вздовж його південних та східних кордонів зон стабільності. Ці прагнення проявилися у так званій Свропейській політиці сусідства (European Neighbourhood Policy), спрямованій на унеможливлення появи нової «залізної завіси» - лінії геополітичного розколу між ЄС та їі східними сусідами.

Імпульси європейської інтеграції ініціювали в країнах Східної Свропи складні й часто неоднозначні соціально-політичні процеси. Причини цього криються у значних відмінностях ідентичності населення країн колишнього Радянського Союзу, його менталітеті та базових цінностях.

Прихильність населення України до європейських ліберально-демократичних цінностей зіштовхнулась 3 авторитарно-консервативними традиціями, які активно пропагувалися та просувалися російською правлячою верхівкою на теренах колишнього Радянського Союзу у формі геополітичного проекту «Русскій мір». Поглиблення цього протиріччя набуло критичної форми і призвело до відкритої інтервенції Росії проти України.

Ця ситуація визначає необхідність активнішої реалізації європейської стратегії сусідства 3 Україною, залучення ефективних механізмів іiі інтеграції до європейського соціально-економічного простору.

М е т а дослідження - розкрити особливості розвитку українсько-угорського прикордоння як важливої територіальної ланки у системі європейської інтеграції України.

\section{Виклад основного матеріалу}

Особливу роль серед прикордонних регіонів відіграє Закарпатська область України, яка межує 3 чотирма країнами Свропейського Союзу - Польщею, Словаччиною, Угорщиною та Румунією. Центральне положення тут займає українськоугорська ділянка кордону, протяжність якої становить 137 км. 3 угорського боку Закарпатська область межує з областю (megye - медьє) Саболч-Сатмар-Берег. За даними перепису населення 2001 р., на території Закарпатської області проживало 151,5 тисяч етнічних угорців (12,1\% населення), що є сприятливим чинником інтенсивного розвитку транскордонного співробітництва (рuс. 1).
Висвітлення цієї проблематики у науковій літературі здійснювалось здебільшого у контексті аналізу функціонування Карпатського єврорегіону і стосувалось законодавчого та фінансового забезпечення українсько-угорського транскордонного співробітництва $[2,4,5,10,11]$, його інституалізації, стратегії, основних форм тощо.

Нормативно-правове забезпечення українсько-угорського транскордонного співробітництва грунтується на основоположних нормах $\mathrm{i}$ принципах, закріплених у базових документах Ради Європи. Основними серед них є Європейська рамкова конвенція про транскордонне співробітництво між територіальними громадами (Мадридська конвенція) та Європейська хартія місцевого самоврядування, прийняті відповідно 21.05.1980 р. та 15.10.1985 р. Ці документи були ратифіковані Верховною Радою в 1993 і 1997 рр. та імплементовані до національного законодавства України.

Основними законодавчими актами, що регламентують транскордонне співробітництво в Україні, є Закони України «Про місцеве самоврядування» (1997р.) та «Про транскордонне співробітництво» (2004 р.).

Регламентація транскордонного співробітництва в Угорщині здійснюється на основі Закону LXV. «Про місцеве самоврядування» (1990р.) та Закону XXIV. «Про ратифікацію Європейської рамкової конвенції про транскордонне співробітництво між територіальними громадами та адміністративними органами» (1997р.).

Загалом сформована законодавча база обох країн дала змогу розробити та укласти низку двота багатосторонніх угод щодо транскордонного співробітництва, його інституалізації. Серед них, насамперед, слід назвати Договір про утворення Карпатського єврорегіону, підписаний міністрами закордонних справ України, Угорщини, Словаччини, Польщі та Румунії 14.02.1993 р. у м. Дебрецен.

Єврорегіони, як форма транскордонної співпраці в Свропі, мають тридцятирічний позитивний досвід розвитку. В основі їх функціонування лежать принципи самоврядування, транскордонної кооперації, рівних повноважень сторін, дотримання внутрішнього законодавства.

Участь в єврорегіонах дозволяє оперативно вирішувати прикордонні проблеми на місцевому рівні, створювати гнучкі господарські структури із залученням зовнішніх інвестицій для будівництва та розширення інфраструктури, налагоджувати 


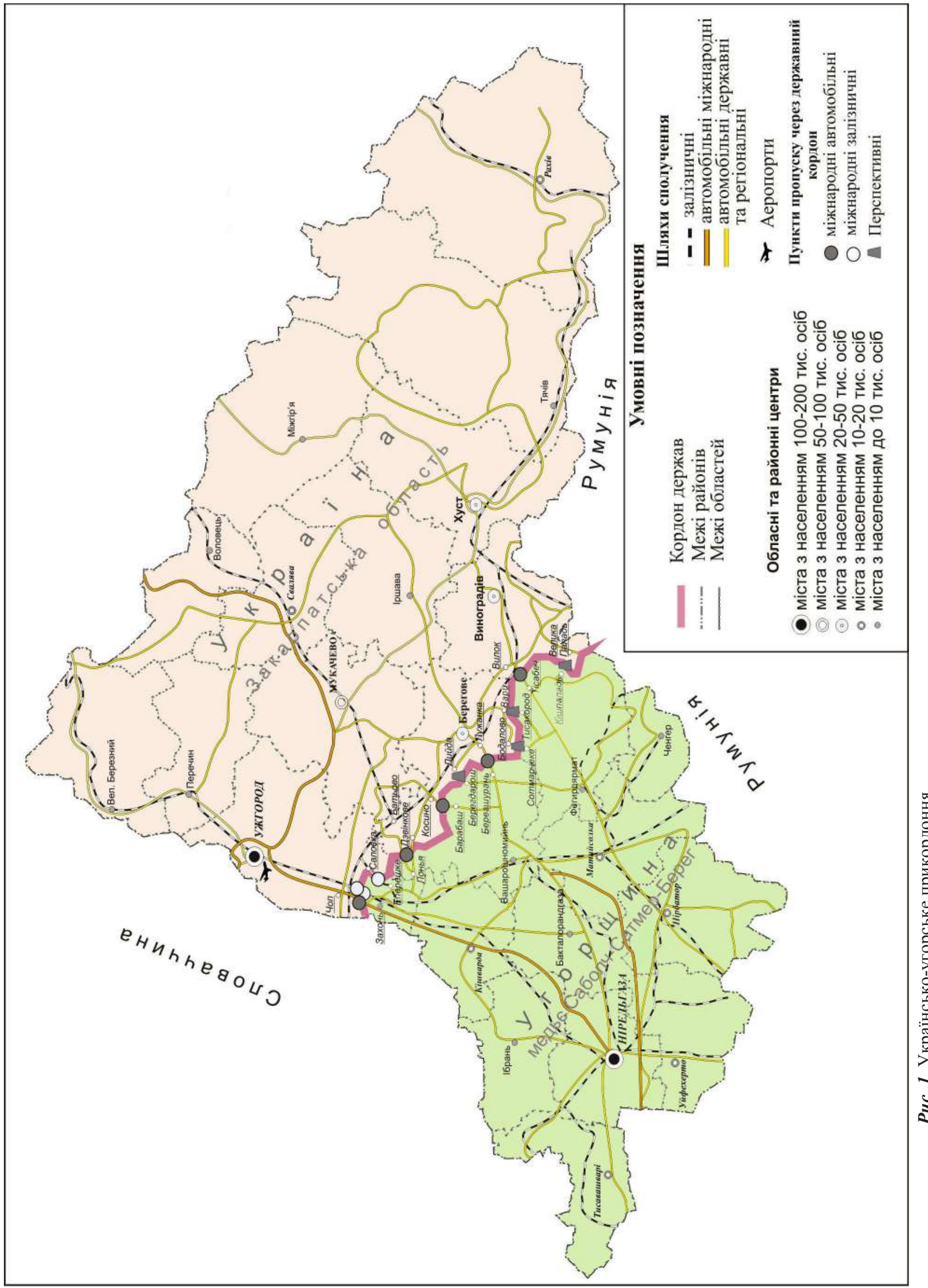


прикордонну торгівлю, туризм, розширювати співробітництво в культурній, соціальній, природоохоронній та інших галузях. Важливим елементом співпраці в рамках єврорегіонів стає спільне обгрунтування і розроблення програм розвитку для отримання фінансових коштів, необхідних для реалізації проектів. Сврорегіони виконують функцію залучення коштів структурних фондів ЄС для вирішення регіональних проблем, розширюють можливості місцевих властей.

Наступним кроком до поглиблення українськоугорського транскордонного співробітництва та його інституційного оформлення стало підписання Угоди між Кабінетом Міністрів України та Урядом Угорської Республіки про транскордонне співробітництво від 11.11.1997 р. та низки інших договірно-правових актів.

У 2000 р. українсько-угорське транскордонне співробітництво отримало новий імпульс розвитку внаслідок підписання Угоди IНTЕРРЕГІО про співробітництво між Закарпатською областю (Україна), медьє Саболч-Сатмар-Берег (Угорщина) та повітом Сату-Маре (Румунія). Основна мета цієї Угоди полягала в активізації соціально-економічного розвитку всього регіону та зростання якості життя його населення на основі використання можливостей транскордонного співробітництва.

На початку 2003 р. Загальні збори медьє Саболч-Сатмар-Берег та Закарпатська обласна рада затвердили Концепцію спільного розвитку прикордонних територій. У жовтні 2003 р. у м. Ужгород було прийнято Стратегію розвитку транскордонного співробітництва у Карпатському регіоні «Карпати 2003-2011». Цей документ був спрямований на забезпечення сталого розвитку на основі рівних можливостей суб'єктів господарювання усіх територій, що входять до Карпатського єврорегіону.

Зі вступом Угорщини до Свропейського Союзу у 2004 р. перед нею постали нові зовнішньополітичні та економічні проблеми і завдання. Насамперед це стосувалося посилення ролі Угорщини в реалізації європейської політики сусідства, активізації заходів щодо розбудови системи міжрегіонального, зокрема транскордонного, співробітництва $з$ Україною.

Реалізація цих заходів розпочалась ще в період підготовки Угорщини до вступу в СС. Так, у 2001 р. $з$ метою адаптації українсько-угорського транскордонного співробітництва до євро- пейських стандартів була розроблена Концепція спільного розвитку прикордонних територій України і Угорщини. 3 урахуванням перспектив європейської інтеграції обох країн ключова роль у цій концепції відводилась створенню умов для ефективних торговельно-економічних відносин, спорудження П'ятого європейського транспортного коридору тощо.

Важливим засобом активізації українськоугорського транскордонного співробітництва стала діяльність Ніредьгазької ініціативи, метою якої є «посилення зв'язків між місцевими та регіональними органами влади на нових східних кордонах Європейського Союзу, розвиток співробітництва та сприяння налагодженню міжрегіонального партнерства, підтримка розвитку співробітництва між суб'єктами економічної діяльності, між представниками науки, культури $\mathrm{i}$ освіти прикордонних регіонів» [4, с. 36].

У рамках Програм європейського інструменту сусідства і партнерства прикордонні регіони України та Угорщини в період 2007-2013 рр. отримували певну організаційну та фінансову підтримку для розвитку транскордонного співробітництва. Ця підтримка загалом регламентувалась Програмою транскордонного співробітництва «Україна - Угорщина - Словаччина - Румунія» і реалізовувалась за такими пріоритетними напрямами як економічний та соціальний розвиток, покращення стану навколишнього середовища, зростання ефективності прикордонної інфраструктури, підтримка співробітництва «люди людям» [2, с. 54]. По кожному 3 цих напрямків здійснювався відбір конкретних інвестиційних проектів, кошти на реалізацію яких на договірних засадах надавалися зацікавленими партнерськими структурами (бенефіціарами).

Серед найзначиміших проектів українськоугорського транскордонного співробітництва, які були реалізовані чи нині реалізуються, слід назвати Програму комплексного протипаводкового захисту в басейні річки Тиса, розвиток мережі автомобільних шляхів у рамках спорудження П'ятого європейського транспортного коридору, організація в Закарпатській області близько 240 спільних українсько-угорських підприємств, створення регіонального туристичного інформаційного центру, українсько-угорської торгово-промислової палати (з центром у м. Ужгород), угорського національного торгового дому (3 центром в м. Ужгород та в м. Берегове) та центру 
українсько-угорського регіонального розвитку, формування мережі партнерських організацій, що працюють у галузі водного та сільського туризму. Тільки за період 2012 - 2014 рр. у рамках угоди між МЗС Угорщини та Закарпатською обласною радою, завдяки співфінансуванню угорської сторони, було реалізовано понад 90 спільних проектів з метою енергозбереження та поточного і капітального ремонту установ соціальної сфери (зокрема, шкіл, дитячих садків, інституцій культури та охорони здоров'я).

Проблеми транскордонного співробітництва висвітлені також у регіональних нормативних документах, програмах і стратегіях. Так, зокрема, серед основних напрямків Регіональної стратегії розвитку Закарпатської області до 2020 р. - поглиблення транскордонного співробітництва 3 медьє Саболч-Сатмар-Берег. При цьому виділяються такі пріоритети: подальший розвиток транспортної мережі та інфраструктури пунктів перетину кордону i логістики; стимулювання створення спільних підприємств; реалізація маркетингових акцій з метою залучення інвестицій; спільні зусилля зі збереження природного середовища прикордонних регіонів; реалізація програм транскордонного співробітництва в галузі освіти, науки, культури і мистецтва; створення спільних інформаційних джерел тощо.

Програма регіонального розвитку медьє Саболч-Сатмар-Берег у $2014-2020$ рр. також включає поглиблення транскордонного співробітництва на українсько-угорському прикордонні. Особлива увага приділяється протипаводковій співпраці у басейні $\mathrm{p}$. Тиса та розвитку інфраструктурної системи (планується продовження автомагістралі М3 до українського кордону, до с. Берегдароц, що інтенсифікувало б логістичну співпрацю між двома регіонами) ${ }^{1}$.

У подальшому розвитку $\mathrm{CC}$ вирішальне значення мають ті ініціативи, які можуть сприяти інтеграції нових членів європейської формації та підтримують цілі їх розвитку. Усвідомивши це, керівні органи медьє Саболч-Сатмар-Берег та Закарпатської області вирішили створити Європейське об'єднання територіального співробітництва (СОТС) «Тиса» (EGTC: European Grouping

${ }^{1}$ The program of regional development 2014 - 2020 Szabolcs-Szatmár-Bereg. URL: http://szszbfejlesztes.hu/ teruletfejlesztesi_program of Territorial Cooperation), яке було зареєстровано 26 жовтня 2015 року у Міністерстві зовнішньої економіки і закордонних справ Угорщини, iз штаб-квартирою у м. Кішварда (Угорщина). Основною метою СОТС «Тиса» $є$ сприяння прикордонному співробітництву країн-членів для реалізації спільних інвестиційних та культурно-освітніх проектів.

«Тиса» $є$ першим СОTС, яке включає країну - не члена СС. Оскільки це об'єднання є самостійною юридичною особою, воно забезпечує не тільки інституційні співробітництва, а й легітимізує використання європейських фінансових джерел поза межами Союзу. Ця міжрегіональна формація $\epsilon$ новою формою співпраці України 3 $€ C$, завдяки якій відкриваються можливості для реалізації спільних транскордонних проектів, передусім за безпосередньої технічної та фінансової допомоги $\mathrm{CC.}$

Визначено такі стратегічні завдання діяльності СОТС «Тиса»:

- всебічно сприяти євроатлантичному зближенню як Закарпатській області, так і Україні загалом, окремим організаціям, підприємствам та громадянам;

- слугувати координатором та розпорядником фінансових ресурсів: об'єднання, з одного боку, може подавати заявки на тендери, а 3 іншого може саме приймати тендерні заявки. Крім створення фінансових джерел, через малопроектний фонд, а також може підтримувати проекти менших масштабів розвитку місцевих громад, громадських організацій та поселень із недостатніми фінансовими можливостями.

- маючи таку перевагу порівняно 3 іншими міжнародними інституційними структурами як статус незалежної юридичної особи, СОТС може наймати працівників по обидва боки кордону, керувати інституціями та некомерційними підприємствами. Це забезпечує можливість створювати спільні установи з метою інтегрованого розвитку тих чи інших господарських структур, економічних транскордонних кластерів тощо.

Отже, зважаючи на досить інтенсивне і тривале транскордонне співробітництво між Закарпатською областю і медьє Саболч-Сатмар-Берег, можна констатувати, що ці адміністративно-територіальні таксони формують українсько-угорський транскордонний регіон.

Нині існує низка трактувань поняття «транскордонний регіон». На основі аналізу цих визна- 
чень у законодавчих ${ }^{2,3}$ документах та науковій літературі можна виділити такі основні риси транскордонного регіону (ТКР) $[6,8,9]$.

1. ТКР формуються на основі суміжних прикордонних субнаціональних адміністративно-територіальних таксонів двох або декількох держав.

2. Адміністративно-територіальні таксони різних країн, що утворюють ТКР, характеризуються подібністю природно-географічних умов та особливостей історичного розвитку і є своєрідними культурними та соціально-економічними перехідними зонами між різними державами.

3. ТКР є територіальним базисом реалізації транскордонного співробітництва, яке являє собою пряму співпрацю в усіх сферах життєдіяльності між регіональними та місцевими органами влади, суб’єктами господарювання, громадськими організаціями, окремими громадянами чи їх групами, що знаходяться по різні боки кордону.

Як засвідчив європейський досвід, транскордонне співробітництво зумовлює виникнення синергії, своєрідної «доданої вартості» в розвиток громад i регіонів по обидва боки кордону. Тому не рідко саме прикордонні регіони характеризуються вищим рівнем соціально-економічного розвитку порівняно з внутрішніми регіонами.

Однак, стосовно Закарпатської області та медьє Саболч-Сатмар-Берег ми мусимо констатувати, що переваги їхнього прикордонного положення для активізації соціально-економічного розвитку повною мірою не використовуються. Як в Україні, так і в Угорщині ці регіони залишаються депресивними.

Індикативним, комплексним показником, що найбільшою мірою характеризує рівень економічного розвитку регіону, слід вважати виробництво валової доданої вартості (value added). Динаміку її виробництва в Закарпатській області та медьє Саболч-Сатмар-Берег в 2001 - 2014 рр. показано в табл. 1.

На Закарпатську область припадає лише близько 1,5 \% від загального обсягу в Україні. Причому, починаючи з 2001 р. цей показник залишався практично незмінним. Не мало також істотного

2 Закон України «Про місцеве самоврядування» URL: http://kodeksy.com.ua/pro_mistseve_samovryaduvannya _v_ukraini.htm

ЗЗакон України «Про транскордонне співробітництво» URL: http://zakon.rada.gov.ua/laws/show/1861-15 впливу на економічний розвиток області та їі місце в економіці України надання у 1998 р. Закарпаттю статусу спеціальної економічної зони.

Показник виробництва валової доданої вартості області у розрахунку на одного мешканця становив у 2013 р. 1982 дол. США і був одним 3 найнижчих в країні - лише 50 \% від аналогічного показника в Україні загалом.

У медьє Саболч-Сатмар-Берег частка виробництва валової доданої вартості становить близько 3\% від іiі загального обсягу в Угорщині. Як і на Закарпатті, упродовж досліджуваного періоду цей показник практично не змінювався, як не змінювалося і співвідношення валової доданої вартості регіону в розрахунку на 1 мешканця до аналогічного показника по всій Угорщині. Цей показник становить тут понад 5800 дол. США на одну особу, що майже у три рази вище ніж у Закарпатській області. Така транскордонна асиметрія зумовлює низку проблем розвитку українсько-угорського транскордонного регіону.

В умовах значних відмінностей в організації регіональної статистики та розходжень у системі статистичних показників двох країн наскрізне дослідження українсько-угорського транскордонного регіону є досить проблематичним. У зв'язку 3 цим влітку 2014 р. нами було здійснено експертне анкетування 93 респондентів, що мешкають у районах, які безпосередньо прилягають до українсько-угорського кордону. По його обидва боки було залучено приблизно однакову кількість експертів-респондентів. До їх числа були включені вчителі географії середніх навчальних закладів та викладачі вищих навчальних закладів, що мають достатньо високий рівень обізнаності щодо стану та проблем розвитку прикордонної території, де вони мешкають.

Анкети включали декілька груп питань, що стосувалися:

1) можливостей та проблем спільного використання наявних на території природних ресурсів 3 метою активізації соціально-економічного розвитку всього транскордонного регіону;

2) трудових ресурсів територіiі, їх зайнятості в суміжних регіонах обох країн;

3) рівня доходів та якості життя населення, що проживає по обидва боки кордону;

4) формування виробничих зв'язків між суб'єктами господарювання, що функціонують на прикордонних територіях обох країн;

5) інтенсивності, спрямованості та мотиваціях 
Таблиця 1

Динаміка виробництва валової доданої вартості (value added) в Закарпатській області України та медьс Саболч-Сатмар-Берег Угорщини

\begin{tabular}{|c|c|c|c|c|c|c|}
\hline Роки & $\begin{array}{c}\text { Валова додана } \\
\text { вартість } \\
\text { області/медьє, } \\
\text { млн дол. США }\end{array}$ & $\begin{array}{c}\text { Валова } \\
\text { додана } \\
\text { вартість } \\
\text { країни, } \\
\text { млн дол. } \\
\text { США }\end{array}$ & $\begin{array}{c}\text { Частка валової } \\
\text { доданої } \\
\text { вартості } \\
\text { області/медьє } \\
\text { в країні, \% }\end{array}$ & $\begin{array}{c}\text { Валова додана } \\
\text { вартість } \\
\text { області/медьє у } \\
\text { розрахунку на } \\
1 \text { мешканця, } \\
\text { дол. США }\end{array}$ & $\begin{array}{c}\text { Валова додана } \\
\text { вартість країни } \\
\text { у розрахунку на } \\
1 \text { мешканця, } \\
\text { дол. США }\end{array}$ & $\begin{array}{c}\text { Співвідношення: } \\
\text { валова додана } \\
\text { вартість області / } \\
\text { медьє у розрахун- } \\
\text { ку на } 1 \text { мешканця } \\
\text { до аналогічного } \\
\text { показника по } \\
\text { країні }\end{array}$ \\
\hline \multicolumn{7}{|c|}{ Закарпатська область, Україна } \\
\hline 2001 & 517,7 & 34123,9 & 1,52 & 411,1 & 701,1 & 0,59 \\
\hline 2002 & 602,8 & 38362,0 & 1,57 & 480,0 & 795,8 & 0,60 \\
\hline 2003 & 753,1 & 45848,8 & 1,64 & 601,4 & 959,0 & 0,63 \\
\hline 2004 & 933,0 & 59840,7 & 1,56 & 746,7 & 1261,0 & 0,59 \\
\hline 2005 & 1213,4 & 77315,3 & 1,57 & 973,1 & 1641,4 & 0,59 \\
\hline 2006 & 1496,6 & 96461,8 & 1,55 & 1202,6 & 2061,8 & 0,58 \\
\hline 2007 & 1949,1 & 130077,6 & 1,50 & 1567,7 & 2796,8 & 0,56 \\
\hline 2008 & 2270,9 & 158037,9 & 1,44 & 1826,9 & 3416,5 & 0,53 \\
\hline 2009 & 1540,4 & 108711,6 & 1,42 & 1238,1 & 2360,6 & 0,52 \\
\hline 2010 & 1832,2 & 126024,2 & 1,45 & 1470,4 & 2747,4 & 0,54 \\
\hline 2011 & 2109,8 & 146517,2 & 1,44 & 1689,1 & 3205,7 & 0,53 \\
\hline 2012 & 2415,6 & 157944,8 & 1,53 & 1928,4 & 3464,2 & 0,56 \\
\hline 2013 & 2486,7 & 167191,8 & 1,49 & 1982,0 & 3491,1 & 0,57 \\
\hline 2014 & 2026,9 & 133354,2 & 1,51 & 1469,2 & 2925,0 & 0,50 \\
\hline \multicolumn{7}{|c|}{ медьс Саболч-Сатмар-Берег, Угорщина } \\
\hline 2001 & 1577 & 48744,7 & 3,23 & 2670 & 4778 & 0,56 \\
\hline 2002 & 2055 & 66959,2 & 3,06 & 3490 & 6577,5 & 0,53 \\
\hline 2003 & 2494 & 78485,1 & 3,17 & 4252 & 7734 & 0,55 \\
\hline 2004 & 3108 & 99113,6 & 3,13 & 5325 & 9795 & 0,54 \\
\hline 2005 & 2780 & 89926,4 & 3,09 & 4780 & 8905 & 0,54 \\
\hline 2006 & 3268 & 108765,1 & 3,00 & 5647 & 10792 & 0,52 \\
\hline 2007 & 3847 & 126576,1 & 3,03 & 6674 & 12572 & 0,53 \\
\hline 2008 & 3572 & 122663,9 & 2,91 & 6253 & 12208 & 0,51 \\
\hline 2009 & 3524 & 118090,4 & 2,98 & 6232 & 11772 & 0,53 \\
\hline 2010 & 3282 & 109156,3 & 3,00 & 5852 & 10899 & 0,54 \\
\hline 2011 & 2879 & 98839,0 & 2,91 & 5181 & 9897 & 0,52 \\
\hline 2012 & 3310 & 108446,0 & 3,05 & 5853 & 10917 & 0,54 \\
\hline 2013 & 3456 & 113543 & 3,04 & 6131 & 11459 & 0.54 \\
\hline 2014 & 3711 & 117430 & 3,16 & 6610 & 11889 & 0.56 \\
\hline
\end{tabular}


транскордонних переміщень жителів обох країн;

6) екологічних проблем розвитку українськоугорського транскордонного регіону.

Як зазначили практично всі експерти, наявні на території транскордонного регіону природні ресурси спільно не використовуються. Кожна країна самостійно використовує свій природно-ресурсний потенціал, виходячи з власних потреб. Ще у радянські часи на території українсько-угорського прикордоння реалізовувались окремі проекти щодо спільного використання сільськогосподарських угідь. Серед них найвідомішим був вирощений українськими та угорськими садоводами яблуневий сад «Дружба» біля с. Астей Берегівського району. Мали місце і поодинокі випадки участі угорської сторони у роботі сільськогосподарських підприємств Закарпатської області, що спеціалізувались на садівництві, виноградарстві та вирощувані тютюну.

Нині є низка ініціатив стосовно спільного використання природних рекреаційних ресурсів у басейні р. Тиса та термальних вод регіону. Наприклад, в м. Берегове спільним підприємством «Водоканал Карпатвіз» реалізовано проект щодо водопостачання міста.

Експерти вказують, що у радянський період можливості переміщення мешканців прикордонних районів Закарпаття до Угорщини були зведені до мінімуму. Формально вони мали право на одне відвідування сусідньої країни упродовж 2 років при наявності там прямих родичів. За міждержавними договорами невелику кількість мешканців Закарпатської області щорічно відправляли на сезонні роботи в сільськогосподарських підприємствах сусідніх регіонів Угорщини.

Режим доступу угорських громадян на територію Закарпаття був дещо спрощеним, однак далеким від вільного переміщення через кордон. За радянських часів у Закарпатській області угорці працювали переважно на будівництві окремих об’єктів соціальної інфраструктури (готель «Закарпаття», м. Ужгород), промисловості (взуттєва фабрика, м. Ужгород), транспорту (будівництво газопроводів) тощо.

У наш час в умовах лібералізації прикордонного режиму ситуація докорінно змінилася. Як вважають респонденти, близько 15 \% працездатного населення прикордонних районів Закарпатської області працюють в Угорщині. Вони зайняті переважно на сезонних сільськогосподарських роботах, будівництві, сфері послуг, догляді за людь- ми похилого віку та дітьми. Лише третина 3 них працевлаштовується в межах медьє Саблоч-Сатмор-Берег, інші їдуть до Будапешта та інших міст Угорщини.

Угорських громадян значно менше працює на спільних підприємствах, що функціонують у Закарпатській області, головним чином у містах Ужгород, Чоп, Берегове та Виноградів.

Територіальні диспропорції у переміщенні робочої сили пов'язані з транскордонною асиметрією у рівнях доходів населення, а відтак - і у якості його життя.

Як показало наше дослідження, середній рівень доходів населення прикордонних районів Угорщини більше ніж у 3 рази перевищує аналогічний показник в Україні. Так, у прикордонних районах Закарпаття середній дохід одного працюючого складає близько 140-150 євро, тоді як в суміжних районах Угорщини він становить понад 450 євро.

Разом 3 тим, більшість українських експертівреспондентів оцінюють якість життя населення у прикордонних районах Закарпатської області як середній та дещо нижчий ніж у сусідніх районах Угорщини. Очевидно, це пов'язано з тим, що громадяни України мають широкі можливості отримувати основний прибуток у сусідній країні, причому, не стільки у прикордонних, а, як уже зазначалось, і в інших, переважно центральних регіонах Угорщини.

Очевидно, що згладжуванню відмінностей у рівнях доходів населення сприяло б формування транскордонних економічних кластерів та інтенсивне нарощування виробничих і трудових зв'язків між суб'єктами господарювання по обидва боки кордону.

Приклади таких зв'язків, розбудови спільних підприємств можна навести передусім у харчовій промисловості. Серед них - ТОВ консервний завод «Універ», побудований у м. Виноградів на основі угорських інвестицій. Передові технології, європейський рівень менеджменту, оригінальна рецептура виробів та їх висока якість дозволили цьому підприємству вийти на третє місце в Україні за обсягами реалізованої продукції. Угорські інвестиції та технології широко використовуються й на інших підприємствах регіону, зокрема на виноробному комплексі «Чизай», ЗАТ СП «Котнар» (м. Берегове).

Крім того, експерти відзначають, що в регіоні функціонує ціла низка спільних малих та середніх спільних підприємств, які формують своєрід- 
ний кластер легкої (швейної) промисловості. Такі підприємства $є$ у м. Берегове та інших населених пунктах області. Найбільшою серед них $є$ швейна фабрика «Хох-Берег» у с. Великі Береги.

Більшість респондентів (понад $75 \%$ ) вважають, що поглиблення прямих зв'язків між підприємствами прикордонних районів України та Угорщини в перспективі визначатиме соціально-економічний розвиток всього транскордонного регіону.

Разом 3 тим, вони вказують на низку чинників, що сповільнюють розвиток цих процесів. Основними серед них є надмірна забюрократизованість в системі управління господарським і регіональним розвитком з обох боків, прояви корупції та складна суспільно-політична ситуація в Україні, тривалий та складний перетин кордонів тощо.

Відміна візового режиму, яка набула чинності 11. 06. 2017 р., та встановлення регулярного і надійного транспортного сполучення між прикордонними районами України та Угорщини сприятиме поглибленню їх соціально-економічної інтеграції. Вже існує низка приватних фірм та осіб, що здійснюють регулярні пасажирські перевезення з Берегова, Мукачева, Виноградова, Ужгорода та інших поселень Закарпаття в Угорщину. Крім того, налагоджено регулярне залізничне сполучення між містами Чоп та Захонь.

Більшість респондентів відмічають, що пасажиропотік 3 прикордонних районів України в Угорщину приблизно у 2 рази більший, ніж у зворотному напрямку.

Крім працевлаштування, основними мотивами поїздок до сусідньої країни є закупівля продовольчих та промислових товарів, ділові контакти, відвідування родичів та близьких, лікування, відпочинок, дозвілля тощо.

Провідне місце у товарообороті українськоугорського прикордоння посідають тютюнові вироби, алкогольні напої та бензин. Зумовлено це значними відмінностями у рівнях цін на дані товари по різні боки кордону. Так, ціна на тютюнові вироби в Україні приблизно у 3 рази нижча ніж в Угорщині, на горілчані вироби - у 3 рази, на бензин - у 2 рази. Асиметрія цін на ці групи товарів та обмежені можливості їх легального перевезення через кордон зумовили значне поширення контрабанди, формування транскордонних злочинних угруповань, що негативно впливає на загальну криміногенну ситуацію прикордоння.

Серед інших груп товарів, які завозять в обох напрямках, можна назвати кондитерські вироби, пиво та безалкогольні напої, продукти традиційної народної кухні (макаронні вироби, спеції тощо), товари легкої промисловості, побутової хімії, косметика та інше. У цих процесах більшою мірою беруть участь громадяни України, які проживають у складніших економічних умовах.

У задоволенні своїх потреб мешканці Закарпаття орієнтуються переважно на такі прикордонні міста Угорщини як Ніредьгаза, Кішварда, Матийсолка, Дебрецен та інші. Незважаючи на досить широкі можливості транспортного сполучення на території українсько-угорського транскордонного регіону, його подальший розвиток потребує удосконалення прикордонної інфраструктури й транспортної мережі. Насамперед йдеться про підвищення якості автомобільних доріг у Закарпатті та облаштування нових переходів через кордон. Більшість респондентів зазначають важливість побудови моста через р. Тиса та облаштування там переходу Бадалове (Україна) - Сотмарчеке (Угорщина), а також переходів Велика Паладь - Кішпаладь, Вари - Тисакород. Важливим заходом, спрямованим на спрощення переходу через кордон, є запровадження спільного митного та паспортного контролю на пунктах пропуску.

Нагальної реалізації потребує і низка масштабних інфраструктурних проектів, серед яких слід назвати запуск інтерсіті «Будапешт - Мукачеве» 3 подальшим продовженням його маршруту до Львова через новий Бескидський тунель. Ще один проект стосується побудови хабу для угорського лоукостера «Wizz Air»в аеропорту Ужгорода чи в Мукачево. Крім того, оперативного вирішення потребує і з'єднання на території Закарпатської області П'ятого панєвропейського транспортного коридору (в межах Угорщини - автобан М3) 3 автомобільною трасою М06 «Чоп - Київ». Для цього необхідно облаштування ще одного переходу через кордон - Берегдароц (Угорщина) - Дийда (Україна).

Дедалі більшого розвитку в регіоні набуває співробітництво в галузі охорони довкілля. Пов'язано це у першу чергу з необхідністю вирішення спільної для прикордонних районів обох країн проблеми запобігання катастрофічних паводків на р. Тиса. 3 цією метою тут облаштовано спільну мережу пунктів спостереження за гідрологічним режимом, яка включає близько 50 пунктів. У перспективі - вирішення проблеми захисту від паводків на р. Тиса, пов'язане із закінченням будівництва дамби біля с. Вишкова (Закарпаття). 
Експерти також наголошують на необхідності розширення мережі заповідних територій. Це стосується насамперед створення спільного національного парку «Верхня Тиса» та розширення заповідника Сатмар-Берег в Угорщині на територію України.

\section{Висновки}

На основі проведеного дослідження можна зробити такі принципові висновки щодо місця і ролі українсько-угорського транскордонного регіону в інтеграції України до європейського соціально-економічного простору.

1. Сприятливе суспільно-географічне та геополітичне положення, особливості історичного розвитку українсько-угорського транскордонного регіону зумовили інтенсивний розвиток тут інтеграційних процесів у соціально-економічному та культурному аспектах. Значною мірою це зумовлено і високою часткою угорців, що проживають у прикордонних районах Закарпаття і мають тісні трудові, культурні, бізнесові та особисті зв'язки 3

\section{Угорщиною.}

2. Регіон став своєрідним полігоном, де апробовуються, адаптуються та поширюються на інші регіони України європейські організаційні, інституційні та інші суспільні інновації.

3. Ефективний розвиток українсько-угорського, як і інших транскордонних регіонів, що формуються $з$ країнами Європейського Союзу, грунтується на утворенні транскордонних економічних кластерів та встановленні прямих зв'язків між суб'єктами господарювання, що знаходяться в прикордонних районах суміжних країн.

4. Євроінтеграційні процеси у різних регіонах України проходять 3 різною швидкістю. Можливості Закарпаття у цьому відношенні є одними із найкращих, що і забезпечує йому значні переваги перед іншими регіонами України.

У найближчій перспективі це відкриває значні можливості для формування тут потужних полюсів соціально-економічного зростання, які поширюватимуть імпульси розвитку на сусідні регіони України.

\section{References [Jimepamypa]}

1. Belokon Yu.D., Fomin I.A. (2002). Territorial organization of cross-border regions (conceptual approaches): monograph. Kyiv. [In Russian].

[Белоконь Ю.Д., Фомин И.А. Организация территорий приграничных районов (концептуальные положения): монография. Киев, 2002. 88 с.]

2. Kish Ye.B. (2013). Innovative potential of cross-border cooperation of Ukrainian and Hungarian regions. Scientific herald of Mykolaiv V.O.Sukhomlynskyi National University: Historical sciences. Issue. 35, 197-201. [In Ukrainian].

[Кіш Є.Б. Інноваційний потенціал транскордонного співробітництва регіонів України та Угорщини // Наук. вісник Миколаївського нац. ун-ту ім. В.О. Сухомлинського. Серія: Історичні науки. 2013. Вип. 35. С. 197-201.]

3. Krasivskyi O., Huzunets Yu. (2008). Ukrainian-Hungarian cooperation in Carpathian Euroregion. Visnyk of the Lviv University. Series Foreign relations. Issue 25, 33 - 39. [In Ukrainian].

[Красівський О., Гузинець Ю. Українсько-угорське співробітництво в рамках Карпатського єврорегіону // Вісник Львівського ун-ту. Серія міжнародні відносини. 2008. Вип. 25. С. 33 - 39.]

4. Kultchar T.F. (2013). Strategic programming of Ukrainian-Hungarian cross-border cooperation. Uzhhorod university scientific herald. Series History. Issue. 28, 50-54. [In Ukrainian].

[Кулчар Т.Ф. Стратегічне програмування українсько-угорського транскордонного співробітництва // Наук. вісник Ужгородського ун-ту. Серія «Історія». 2013. Вип. 28. С. 50 - 54.]

5. Kultchar T.F. (2013). Financial dimension of Ukrainian-Hungarian cooperation in 2004-2013. Uzhhorod university scientific herald. Series History. Issue. 31, 51 - 56. [In Ukrainian].

6. [Кулчар Т.Ф. Фінансовий вимір українсько-угорського співробітництва у 2004-2013 роках // Наук. вісник Ужгородського ун-ту. Серія «Історія». 2013. Вип. 31. С. 51 - 56.]

7. Mikula N. (2004). Interterritorial and cross-border cooperation. Lviv. [In Ukrainian].

[Мікула Н. Міжтериторіальне та транскордонне співробітництво. Львів, 2004. 395 с.]

8. Podgrushnyi G.P. (2010). Ukrainian-Russian-Belarus cross-border region: formation factors, peculiarities of territorial organization, problems and perspectives of development. Human Geography Issues. Borderlands: Methodological approaches and research experience. Сборник научных трудов. Kiev, Issue. 2, 38 - 45. [In Russian].

[Подгрушный Г.П. Украинско-российско-белорусский трансграничный регион: факторы формирования, особенности территориальной организации, проблемы и перспективы развития // Проблемы общественной географии. Приграничные территории: методологические подходы и опыт исследований: Сб. науч. трудов. Киев. Вып. 2. 2010. C. 38 - 45.]

9. Studennikov I. (2000). Regional policy in countries of Europe: Lessons for Ukraine. Kyiv. [In Ukrainian].

[Студенніков I. Регіональна політика в країнах Європи: Уроки для України. Київ, 2000. С. 12.]

10. Cross-border cooperation and development of cross-border clusters. (2009). Kyiv. [In Ukrainian]. 
[Транскордонне співробітництво та розвиток транскордонних кластерів. Київ, 2009. 242 с.]

11. Tsisinska O.B. (2011). The influence of regional management on convergence of Ukrainian-Hungarian cross-border region. Socio-Economic issues of modern Ukraine. Regional convergence and cross-border markets. Issue. 5 (91), 90 112. [In Ukrainian].

[Цісінська О.Б. Вплив регіонального менеджменту на конвергенцію українсько-угорського транскордонного регіону // Соціально-економічні проблеми сучасного періоду України. Регіональна конвергенція та транскордонні ринки. 2011. Вип. 5 (91). С. 90 - 112.]

12. Perkmann M. (2003). Cross-Border Regions in Europe. Significance and Drivers of Regional Cross-Border Co-Operation. European Urban and Regional Studies, 10, 153-171.

Стаття надійшла до редакції 1.11.2017

УДК $911.3 .30(477)$

https://doi.org/10.15407/ugz2017.04.030

М.O. Барановський

Ніжинський державний університет імені Миколи Гоголя

\section{ФІНАНСОВА ДЕЦЕНТРАЛІЗАЦІЯ В УКРАЇНІ: ОСОБЛИВОСТІ СТАНОВЛЕННЯ}

Мета публікації - оцінювання особливостей становлення фінансової децентралізації в Україні, рівня фінансової автономії територіальних громад, їі регіональних відмінностей та причин, що їх зумовлюють. Фінансова децентралізація, яка передбачає концентрацію ресурсів на низовому рівні управління, є важливим інструментом вирішення проблеми формування самодостатніх територіальних громад. У процесі іiі проведення окреслилися проблемні аспекти, зокрема територіальні диспропорції у фінансовій спроможності громад. У статті проаналізовано динаміку загальних доходів об'єднаних територіальних громад України, структуру та регіональні відмінності їніх власних податкових надходжень. Встановлено, що фінансово автономними є лише близько 20 \% територіальних громад. Проведено типізацію громад за фінансовими характеристиками, визначено високий рівень дотаційності бюджетів територіальних громад західних регіонів країни. За допомогою кореляційно-регресійного аналізу встановлено, що найістотніше на фінансову автономію територіальних громад впливають загальноекономічні показники розвитку регіонів, розміри самих громад і статус їхньго центра. Доведено, що фінансові преференції поки що не відіграють провідної ролі у процесі формування територіальних громад, а значна частина з них створена без належного економічного підгрунтя. Визначено інструменти, запровадження яких дасть можливість збільшити доходну частину, насамперед периферійних територіальних громад.

Ключові слова: фінансова децентралізачія; об'єднана територіальна громада; самодостатня громада; структура доходів громад; рівень дотаційності бюджетів громад.

\section{O. Baranovskyi}

Nizhyn Mykola Gogol State University

FINANCIAL DECENTRALIZATION IN UKRAINE: PECULIARITIES OF IMPLEMANTATION

The purpose of the publication is to estimate the specifics of formation of the financial decentralization in Ukraine, the level of financial autonomy of territorial communities, its regional differences, and the reasons that predetermine them. Financial decentralization, which presupposes the concentration of resources at the grassroots level of government is an important tool to solve the problem of the formation of self-sufficient territorial communities is As a result of its implementation, certain problem aspects emerged, in particular territorial disproportion in the financial capacity of communities. The article analyzes the dynamics of the total incomes of the amalgated territorial communities of Ukraine, the structure and regional differences of their own tax revenues. It is defined that only $20 \%$ of territorial communities are financially autonomous. The typification of communities by financial characteristics was carried out, the high level of subsidies for the territorial communities budgets of the western regions of the country was determined. With the help of correlation-regression analysis it was established that the general economic indicators of the regions development, the size of the communities, and the status of their center have

() М.О. Барановський, 2017 